\title{
KARAKTERISTIK SPORA PTERIDOPHYTA DI PERKEBUNAN KELAPA SAWIT MASYARAKAT DESA BUKIT SELAMAT, KECAMATAN BESITANG, SUMATERA UTARA
}

\section{CHARACTERISTICS OF SPORTS OF PTERIDOPHYTA IN OIL PALM PLANTATION, BUKIT SELAMAT VILLAGE, BESITANG SUB-DISTRICT, NORTH SUMATERA}

\author{
Miranda Dwi Rahayu', Elfrida ${ }^{2}$, Adi Bejo Suwardi ${ }^{3}$, \\ Prodi Pendidikan Biologi, Fakultas Keguruan Ilmu dan Pendidikan, \\ Universitas Samudra \\ Email : mirandadwirahayu312@gmail.com
}

\begin{abstract}
ABSTRAK
Karakteristik morfologi spora dapat diidentifikasi melalui bentuk, ukuran dan tipe laesura spora. Karakteristik spora tumbuhan yang telah di identifikasi bisa menentukan spesies tumbuhan paku yang nantinya berfungsi untuk pengklasifikasian. Penelitian ini bertujuan untuk mengetahui bentuk spora dan tipe leasura spora pada tumbuhan Pterydophyta yang terdapat pada perkebunan kelapa sawit masyarakat di desa Bukit Selamat, Kecamatan Besitang, Sumatera Utara. Penelitian ini dilaksanakan selama 3 bulan di perkebunan kelapa sawit masyarakat desa Bukit Selamat. Metode yang digunakan yaitu eksplorasi dengan teknik area sampling. Peneliti menemukan 11 spesies tumbuhan Pterydophyta dengan bentuk membulat, ginjal, ellips dan segitiga serta 2 tipe laesura yaitu monolete dan trilete. Perlu dilakukan Penelitian lanjutan dengan metode yang berbeda di perkebunan kelapa sawit masyarakat di desa Bukit Selamat, Kecamatan Besitang, Sumatera Utara dan pengamatan spora sebaiknya menggunakan SEM (Scanning electron microscope).
\end{abstract}

Kata Kunci: Pteridophyta, Karakteristik Spora.

\section{ABSTRACT}

The morphological characteristics of the spores can be identified through the shape, size and type of spore laesura. The characteristics of plant spores that have been identified can determine the species of ferns which will later function for classification. This study aims to determine the form of spores and the type of spore leasura on Pterydophyta plants found in community oil palm plantations in the village of Bukit Selamat, Besitang District, North Sumatra. This research was carried out for 3 months in the oil palm plantation of the Bukit Selamat village community. The method used is exploration with area sampling technique. Researchers found 11 species of Pterydophyta plants with rounded, kidney, elliptical and triangular shapes and 2 types of laesura, namely monolete and trilete. Further research is needed with different methods in community oil palm plantations in the village of Bukit Selamat, Besitang District, North Sumatra and the observation of spores should use SEM (Scanning electron microscope).

Keywords: Pteridophyta, Spore Characteristics. 


\section{PENDAHULUAN}

Tumbuhan paku (Pterydophyta) tersebar diseluruh dunia khususnya di kawasan negara tropis dan tumbuhan paku tidak dapat hidup di daerah bersalju abadi dan daerah kering (gurun). Diperkirakan diseluruh dunia terdapat 2 jutaan spesies tumbuhan yang telah dikenali dan $60 \%$ dari jumlah tersebut terdapat di Indonesia. Indonesia merupakan salah satu negara tropis yang memiliki keanekaragaman jenis tumbuhan paku tinggi. Indonesia memiliki lebih dari 4.000 spesies tumbuhan paku-pakuan (LBN-LIPI :1980). Keanekaragaman tumbuhan paku di provinsi Sumatera utara khususnya di kawasan hutan Batang Toru Blok Barat, Kabupaten Tapanuli Utara terdapat 52 spesies tumbuhan paku (Lisna, 2020) dan terdapat 42 spesies tumbuhan paku di bukit Simarsayang Padang Sidimpuan (Siregar, 2014). Tumbuhan paku tergolong dalam jenis tumbuhan yang bersifat kosmopolit atau mudah ditemukan di beberapa habitat. Tumbuhan paku dapat tumbuh di tempat yang lembab, dibawah pepohonan, di pinggir jalan maupun sungai, melihat cara tumbuhnya tumbuhan paku di alam cukup beragam, ada yang epifit, terestrial, aquatik dan likofit.
Karakteristik morfologi spora dapat diidentifikasi melalui bentuk, ukuran dan tipe laesura spora. Karakteristik spora tumbuhan yang telah di identifikasi bisa menentukan spesies tumbuhan paku yang nantinya berfungsi untuk pengklasifikasian. Kajian mengenai karakteristik spora telah dilakukan oleh Sofiyanti et al. (2020) yang mengidentifikasi 23 spesies tumbuhan paku memiliki 2 tipe laesura spora yaitu monolete dan trilete dengan bentuk bulat, ginjal, ellips, dan segitiga di pulau Rangsang Kepulauan Meranti, Provinsi Riau dan 5 spesies tumbuhan paku yang bergenus Asplenium memiliki tipe laesura spora yaitu monolete dengan bentuk ellips di kawasan Hutan Raya R. Soerjo Pranita et al. (2017). Kajian mengenai karakteristik spora juga telah dilakukan oleh Nurchayati (2016) yang mengidentifikasi 10 spesies tumbuhan paku memiliki tipe monolete dan trilete dengan 5 bentuk spora yaitu segitiga, ellips, ginjal, membulat dan segi tak beraturan di Banyuwangi. Ketiga peneliti menyimpulkan bahwa Asplenium nidus L. dengan habitat epifit memiliki tipe laesura monolete dengan bentuk seperti ginjal dan genus Adiantum dengan habitat terestrial memiliki tipe laesura trilete dengan bentuk segitiga atau membulat. 
Berdasarkan penelitian sebelumnya terdapat spesies yang berbeda pada habitat yang berbeda dan berbeda pula karakter spora yang terdapat pada masing-masing spesiesnya. Karakter morfologi spora di perkebunan kelapa sawit belum banyak di teliti terutama di perkebunan kelapa sawit masyarakat Desa Bukit Selamat, Kecamatan Besitang, Sumatra Utara belum pernah diteliti.

Oleh karena itu perlu dilakukan penelitian tentang karakteristik spora Pteridophyta di perkebunan kelapa sawit masyarakat Desa Bukit Selamat, Kecamatan Besitang, Sumatera Utara.

Penelitian ini bertujuan untuk mengetahui bentuk spora dan tipe laesura spora pada tumbuhan Pterydophyta yang terdapat pada perkebunan kelapa sawit masyarakat di desa Bukit Selamat, Kecamatan Besitang, Sumatera Utara.

\section{METODOLOGI PENELITIAN}

\section{Tempat dan Waktu}

Penelitian ini dilaksanakan di perkebunan kelapa sawit masyarakat di desa Bukit Selamat, Kecamatan Besitang, Sumatera Utara dan pengamatan bentuk spora pada Pteridophyta dilakukan di Laboratorium Dasar Universitas Samudra. Penelitian ini dilaksanakan selama 3 bulan.

\section{Alat dan Bahan}

Alat-alat yang digunakan yaitu Kamera, Mikroskop, Laptop, Gunting, Alat tulis, Kaca pembesar, Objek glass, Cover glass. Bahan yang digunakan yaitu Pterydophyta, Buku Lapangan Pteridophyta, Plastik, Kertas label dan Aquades.

\section{Metode Penelitian}

Metode yang digunakan dalam penelitian ini adalah metode eksplorasi yaitu menjelajahi setiap sudut area suatu lokasi yang dapat mewakili tipe ekosistem di kawasan perkebunan kelapa sawit masyarakat di desa Bukit Selamat, Kecamatan Besitang, Sumatera Utara. Penelitian ini menggunakan teknik Area Sampling yaitu teknik pengambilan sampel dilakukan dengan mempertimbangkan wakil-wakil dari daerah geografis yang ada (Fachrul, 2007). Perkebunan kelapa sawit masyarakat desa Bukit Selamat, Kecamatan besitang, Sumatera Utara memiliki 3 tipe lokasi: lokasi pertama adalah di tepi perkebunan dekat jalan yang langsung terkena sinar matahari, lokasi yang kedua adalah di dalam kebun yang terkena sedikit matahari (dibawah naungan), dan lokasi yang ketiga adalah di dekat aliran air atau paret. 
HASIL DAN PEMBAHASAN

\begin{tabular}{|c|c|c|}
\hline $\begin{array}{c}\text { Nama } \\
\text { Spesies }\end{array}$ & $\begin{array}{l}\text { Tipe } \\
\text { Spora }\end{array}$ & $\begin{array}{c}\text { Bentuk } \\
\text { spora }\end{array}$ \\
\hline $\begin{array}{l}\text { Adiantum } \\
\text { peruvianum } \\
\text { Klotzsch. }\end{array}$ & Trilete & Membulat \\
\hline $\begin{array}{l}\text { Asplenium } \\
\text { nidus } \mathrm{L} .\end{array}$ & Monolete & Ginjal \\
\hline $\begin{array}{l}\text { Blechnum } \\
\text { orientale L. }\end{array}$ & Monolete & Membulat \\
\hline $\begin{array}{l}\text { Christella } \\
\text { parasitica } \\
\text { (L.) H.Lév. }\end{array}$ & Monolete & Ginjal \\
\hline $\begin{array}{l}\text { Cyclosorus } \\
\text { heterocarpu } \\
\text { s (Blume) } \\
\text { Ching. }\end{array}$ & Monolete & Ellips \\
\hline $\begin{array}{l}\text { Davallia } \\
\text { denticulata } \\
\text { (Burm.f.) } \\
\text { Mett. }\end{array}$ & Monolete & Ellips \\
\hline $\begin{array}{l}\text { Dicranopter } \\
\text { is linearis } \\
\text { (Burm.f.) } \\
\text { Underw. }\end{array}$ & Trilete & Segitiga \\
\hline $\begin{array}{l}\text { Diplazium } \\
\text { esculentum } \\
\text { (Retz.) Sw. }\end{array}$ & Monolete & Ginjal \\
\hline $\begin{array}{l}\text { Haplopteris } \\
\text { angustifolia } \\
\text { (Blume) E. }\end{array}$ & Monolete & Ginjal \\
\hline
\end{tabular}

\begin{tabular}{|l|l|l|}
\hline H. Crane. & & \\
\hline $\begin{array}{l}\text { Nephrolepis } \\
\text { biserrata } \\
\text { (Sw.) Schott }\end{array}$ & Monolete & Ellips \\
\hline $\begin{array}{l}\text { Pronephriu } \\
m\end{array}$ & Monolete & Ginjal \\
triphyllum & & \\
(Sw.) & & \\
Holttum & & \\
\hline
\end{tabular}

Berdasarkan hasil penelitian menunjukkan bahwa terdapat 11 jenis tumbuhan paku (Pteridophyta) yang ditemukan di perkebunan kelapa sawit masyarakat desa Bukit Selamat, Kecamatan Besitang, Sumatera Utara. Berdasarkan hasil pengamatan dibawah mikroskop dengan perbesaran 40, dari ke-11 tumbuhan Pteridophyta terdapat 4 bentuk spora dan 2 tipe laesura pada spora. Bentuk spora yang terdapat pada tumbuhan Pteridophyta di perkebunan kelapa sawit masyarakat desa Bukit Selamat, Kecamatan Besitang, Sumatera Utara terdiri dari 4 bentuk, bentuk spora yang yang pertama yaitu membulat dengan jumlah 2 jenis dari tumbuhan Pteridophyta yaitu Adiantum peruvianum Klotzsch dan Blechnum orientale L., yang kedua adalah bentuk seperti ginjal (reniformis) dengan jumlah 5 jenis dari tumbuhan Pteridophyta yaitu Asplenium nidus L., 
Jurnal Jeumpa, 8 (1) Januari -Juni 2021

Christella parasitica (L.) H.Lév., Nephrolepis biserrata (Sw.) Schott, dan Diplazium esculentum (Retz.) Sw., Pronephrium triphyllum (Sw.) Holttum., Haplopteris angustifolia (Blume) E. H. yang kedua adalah tipe trilete dengan Crane, dan Pronephrium triphyllum jumlah 2 jenis dari tumbuhan (Sw.) Holttum, yang ketiga adalah Pteridophyta yaitu Adiantum bentuk ellips dengan jumlah 3 jenis dari peruvianum Klotzsch, dan Dicranopteris tumbuhan Pteridophyta yaitu linearis (Burm.f.) Underw. Hal Ini Cyclosorus heterocarpus (Blume) sesuai dengan pernyataan Morley (1990) Ching, Davallia denticulata (Burm.f.) Mett. dan Nephrolepis biserrata (Sw.) Schott, dan yang keempat adalah bentuk segitiga dengan jumlah 1 jenis dari tumbuhan Pteridophyta yaitu Dicranopteris linearis (Burm.f.) Underw. Hal Ini sesuai dengan penelitian Nurchayati (2016) yang menyatakan bahwa bentuk spora ada berbagai macam diantaranya adalah Membulat, Ginjal (reniformis), Ellips, dan Segitiga. Tipe laesura spora yang terdapat pada tumbuhan Pteridophyta di perkebunan kelapa sawit masyarakat desa Bukit Selamat, Kecamatan Besitang, Sumatera Utara terdiri dari 2 tipe, tipe laesura spora yang paling banyak adalah tipe monolete dengan jumlah 9 jenis dari tumbuhan Pteridophyta yaitu Asplenium nidus L., Blechnum orientale L., Christella parasitica (L.) H.Lév., Cyclosorus heterocarpus (Blume) Ching, Davallia denticulata (Burm.f.) Mett., Diplazium esculentum (Retz.) Sw., Haplopteris angustifolia (Blume) E. H. Crane, dalam Nugroho (2014) dan penelitian Nurchayati (2016) yang menyatakan bahwa Tipe laesura spora ada monolete dan trilete.

\section{KESIMPULAN}

Berdasarkan hasil penelitian dan pembahasan dapat disimpulkan bahwa :

1. Bentuk spora pada tumbuhan Pteridophyta yang terdapat pada perkebunan sawit masyarakat di desa Bukit Selamat, Kecamatan Besitang, Sumatera Utara ada 4 yaitu Membulat, Ginjal (reniformis), Ellips, dan Segitiga.

2. Tipe laesura spora tumbuhan Pteridophyta yang yang terdapat pada perkebunan sawit masyarakat di desa Bukit Selamat, Kecamatan Besitang, Sumatera Utara ada dua yaitu monolete dan trilete.

\section{DAFTAR PUSTAKA}

Fachrul, M. F. 2007. Metode Sampling Bioekologi. PT Bumi Aksara : Jakarta. 
LBN-LIPI. 1980. Jenis Paku Indonesia. Balai Pustaka: Jakarta.

Lisna, Rince Gustia. 2020. Skripsi (Inventarisasi Tumbuhan Paku Kelas Filicinae Di Kawasan Hutan Batang Toru Blok Barat Kabupaten. Universitas Sumatera Utara : Medan.

Morley, R. J. 1990. Short Course Introduction To Palynology With Emphasis On Southeast Asia. Fakultas Biologi UNSOED : Purwokerto.

Nugroho, S. H. 2014. Karakteristik Umum Polen dan Spora Serta Aplikasinya. Oseana. 39(3): 719.

Nurchayati, N. 2016. Identifikasi Profil Karakteristik Morfologi Dan Prothalium Tumbuhan Paku Familia Polipodiacea. Jurnal Bioedukasi. 14(2): 25-30.

Pranita, H. S., Susriyati, M., dan Murni S. S. 2017. Karakteristik Spora Tumbuhan Paku Asplenium Kawasan Hutan Raya R. Soerjo. Jurnal Pendidikan. 2(4): 454458.

Siregar, Fadlila Yuhana. 2014. Tesis (Analisis Vegetasi Tumbuhan Paku Berdasarkan Ketinggian di Bukit Simarsayang padang Sidimpuan. Unimed : Medan.

Sofiyanti, N., Afni, A. M., Rissan, S., dan Syafroni, P. 2020. Jenis-Jenis Tumbuhan Paku di Pulau Rangsang, Kepulauan Meranti, Riau dan Karakteristik Morfologi-Palinologi. Jurnal Biologi Tropis. 20(1): 102-110. 